\title{
PROF. DR. SC. DRAGO ROKSANDIĆ - POVJESNIČAR I NASTAVNIK
}

\footnotetext{
$\mathrm{D}$
} rago Roksandić rođen je u Petrinji, 12. siječnja 1948. godine. Osnovno je školovanje stjecao u Sisku, Čapljini, Mostaru te Zagrebu. Pred kraj gimnazijskog školovanja, kada je već obnašao i funkciju sekretara Općinskog komiteta Saveza omladine Hrvatske Zagreb - Centar, zbog različitih je obveza maturirao kao privatni đak u lipnju 1966. godine s odličnim uspjehom. Budući da ga je posebno zanimala kritička teorija društva, upisao je studij filozofije i engleskog jezika (nakon jednog semestra engleski je zamijenio studijem sociologije) 1966. godine na Filozofskom fakultetu u Zagrebu. Interes prema filozofiji pokazivao je od gimnazijskih dana jer od prvog broja (1964.) čita časopis Praxis i prati ljude oko njega. Kasnije se uključuje i u praćenje otvorenih redakcijskih sastanaka u Klubu sveučilišnih nastavnika, upoznajući se s dijaloškom kulturom i funkcioniranjem takvih uredništava. ${ }^{1}$ Zbog radnih obveza u Beogradu od proljeća 1969. godine, studij filozofije i sociologije nije završio. Naime, od 1967. pa do 1971. godine u Zagrebu i Beogradu angažiran je kao profesionalni političar. Kao predsjednik Komisije za međunarodne odnose Predsjedništva Saveza (socijalističke) omladine Jugoslavije intenzivno putuje u bliže i dalje inozemstvo: između 1971. i 1974. godine posjetio je tako u jednom ili više navrata Italiju, Austriju, Mađarsku, Rumunjsku, Bugarsku, Čehoslovačku, Poljsku, DR Njemačku, SR Njemačku, Dansku, Norvešku, Finsku, Francusku, Belgiju te Egipat, Tunis, Alžir, Gvineju, Tanzaniju, Šri Lanku, Indiju, Bangladeš, Sjedinjene Američke Države i Kanadu.

Interes prema povijesti inicijalno se u Roksandića razvija još u Osnovnoj školi „Rudi Čajavec" kod Branka Siroglavića i profesorice povijesti u V. gimnaziji Fani Radovani. Na Filozofskom fakultetu u Beogradu upisao je konačno studij povijesti u akademskoj godini 1971./1972., već tada s izraženom željom da se specijalizira za proučavanje povijesti Vojne krajine. Godine 1975. Roksandić je, nakon četiri godine, prvi u svojoj generaciji završio studij s prosjekom ocjena 9,42. ${ }^{2}$ Tema diplomskog rada bila mu je Hrvatska u doba Marije Terezije (1740-1780). Naredne akademske godine na istom je fakultetu upisao poslijediplomski studij. Između siječnja 1978. i travnja 1979. potom radi u izdavačkom centru „Komunist”, na poziv tadašnjega glavnog urednika Davida Atlagića. Potom prelazi na pripravničko radno mjesto na Filozofskom fakultetu Univerziteta u Beogradu na Katedri za istoriju naroda Jugoslavije u Novom veku. Na fakultet dolazi na poziv Vasilija Krestića, kojemu je bio asistent, dok će kasnih 1980-ih godina biti asistent i Miloradu Paviću. Kao istraživač boravi u zagrebačkim arhivima. Kao stipendist austrijske Vlade boravi pet mjeseci u Beču, na preporuku profesorâ iz Beograda i Zagreba (koju je podržao kao dopisni član SANU i povjesničar Richard Georg Plaschka), s istaživačkom temom „Primorska krajina u 18. stoljeću“. Njegova su istraživanja bila priprema materijala za magistarski rad Bune u Senju i Primorskoj krajini 1719.-1722. godine koji je obranio 1980. godine i koji je dvije

1 Usp. usmeni iskaz objavljen u: Viktorija Antolković - Valentina Nedeljko - Francesca Vudrag, "Lipanjska gibanja: oralna historija studentskih demonstracija na Filozofskom fakultetu 1968. godine“, Pro tempore, 10/11, 2016, 92-128, ovdje 98 te Drago Roksandić, U NIN-u i Danasu, Zagreb 2011, 17.

2 Roksandić, U NIN-u i Danasu, 18. 
godine kasnije objavljen u Radovima Instituta za hrvatsku povijest Sveučilišta u Zagrebu. Nakon što je magistrirao, izabran je 1980. u zvanje asistenta na istoj Katedri za istoriju naroda Jugoslavije u Novom veku.

Godine 1979. uređuje i poseban broj časopisa Marksizam u svetu s temom „Rasprava o prelazu iz feudalizma u kapitalizam“, koja je uključivala tada aktualne debate svjetske historiografije (među ostalima i M. Dobb, R. Brenner, G. Procacci, E. Hobsbawm, A. Soboul i dr.). Time već na početku svoje stručne karijere izaziva pozornost i pokazuje zanimanje za međunarodne teorijske rasprave i njihovu primjenu. Od početka 1980-ih godina Drago Roksandić surađuje i u časopisu Naše teme, na poziv uredništva, upravo zbog njegova šrrokog interesa za teorijske probleme. Od 1983. suradnik je u NIN-u. Tijekom školovanja i daljnjeg znanstvenog usavršavanja u Beogradu Roksandić dolazi u dodir s novim tendencijama europske historiografije, naročito s povjesničarima oko časopisa Annales koji su svojim radovima i pristupom promovirali "novu povijest“. U sklopu rada na doktorskoj disertaciji o Hrvatskoj krajini pod francuskom vlašću (1809. - 1813.) akademsku godinu 1980./1981. proveo je u Francuskoj kao stipendist tamošnje Vlade. Istraživao je u više arhiva i knjižnica u Parizu i izvan njega (Archives Marmont, Châtillon-sur-Seine). U Parizu je istovremeno redovito sudjelovao u radu nekoliko doktorandskih kolegija na l'École des hautes études en sciences sociales kao upisani slobodni slušatelj (étudiant libre) te pratio specijalističke kolegije u Institutu za povijest francuske revolucije na Université Paris 1. Na njega pritom poseban dojam kao nastavnici i stručnjaci ostavljaju Louis Bergeron, Paul-Henri Stahl, Hervé Le Bras te Pierre Vilar, u čijim je istraživanjima pronašao komplementaran model za vlastita problemski orijentirana propitivanja, povezujući dostignuća francuskih Annales sa suvremenim marksističkim metodama. ${ }^{3}$ Doktorsku disertaciju Hrvatska vojna krajina pod francuskom vlašću (1809-1813) (dvije knjige), izvorno prijavljenu na Filozofskom fakultetu u Beogradu, obranio je 1988. na Filozofskom fakultetu u Zagrebu. Disertaciju je ocijenilo povjerenstvo u sastavu: prof. dr. sc. Josip Adamček (predsjednik), prof. dr. sc. Vasilij Melik i prof. dr. sc. Nikša Stančić, a pred istim je povjerenstvom 10. ožujka 1988. godine disertacija i obranjena. Iste godine iz tiska izlazi i monografija Vojna Hrvatska - La Croatie militaire. Krajiško društvo u Francuskom Carstvu (1809-1813) u dvama svescima. Upravo se u toj knjizi vide utjecaji socijalne i kulturne historije te regionalnih studija. Prije svega, riječ je o utjecajima francuskih povjesničara na presijecanju druge (Braudelove) i treće generacije povjesničara oko časopisa Annales, kao što su P. Vilar i drugi, ali i drugih stručnjaka orijentiranih prema regionalno-monografijskim interpretacijama po obrascu humane geografije, brojnih marksističkih povjesničara i suvremenih istraživača koji su obuhvaćali međuodnos endogenih i egzogenih kulturnih fenomena. ${ }^{4} U$ kontekstu političkih promjena u Srbiji i otežanog odnosa s nekadašnjim mentorom, isključen je iz nastave na Odelenju za istoriju Filozofskog fakulteta u Beogradu te je njegova doktorska disertacija prebačena na Filozofski fakultet u Zagrebu. ${ }^{5}$ Nakon što je postigao doktorski stupanj

3 V. Isti, "The Annales School, EHESS, and École de Paris; memories of an étudiant libre in 1980/1981“, u: Annales in Perspective: Designs and Accomplishments, vol. 1, ur. Drago Roksandić - Filip Šimetin Šegvić - Nikolina Simetin Šegvić, Zagreb 2019, 443-450.

4 O recepciji djela i stručnoj raspravi oko knjige v. naročito temat „Krajiška refeudalizacija i počeci modernizacije“, Naše teme, 33/7-8, 1989, 1912-1954, u koji su uključeni prilozi Igora Karamana, Miroslava Bertoše, Dragutina Pavličevića, Galiba Šljive, Ive Perića, Agneze Szabo, Zvonka Kovača, Fedora Moačanina, Ivana Jurišića, Mirjane Gross, Nevija Šetića i Frane Barasa.

5 V. "Univerzitet i moralnopolitička podobnost“, Naše teme, 34/3-4, 1990, 516-600. 
1988., krajem iste godine izabran je u zvanje znanstvenog suradnika na Filozofskom fakultetu u Zagrebu. Godine 1990. izabran je za docenta na Katedri za svjetsku povijest na Odsjeku za povijest Filozofskog fakulteta u Zagrebu na kolegiju „Opća povijest novog vijeka od 16. st. do 1870.“, a 1997. godine u znanstveno-nastavno zvanje izvanrednog profesora za znanstveno područje humanističkih znanosti (povijesne znanosti) za kolegij „Svjetska povijest novog vijeka“. Godine 2003. izabran je u znanstveno-nastavno zvanje redovitog profesora u humanističkom znanstveno-nastavnom području, polje povijest. $U$ lipnju 2008. godine na Senatu Sveučilišta u Zagrebu izabran je za redovitog profesora u trajnom zvanju. $U$ isto je vrijeme na Fakultetskom vijeću Filozofskog fakulteta u Zagrebu izabran za šefa Katedre za povijest Srednje i Jugoistočne Europe Odsjeka za povijest koju je vodio do odlaska u mirovinu 2018. godine.

Nakon što je doktorirao, boravio je 1988. godine kao gostujući predavač (visiting lecturer) na sveučilištu Yale u SAD-u i na Filozofskom fakultetu u Zadru. Između 1991. i 1992. godine bio je gost-istraživač u bečkom Institut für die Wissenschaften vom Menschen, gdje je u četverogodišnjem razdoblju bio i dopisni član kao jedan od utemeljitelja i voditelja istraživačkog projekta "Re-Thinking the Post-War History of Europe“ (zaključenog 1997. godine). Na tom se Institutu okupila skupina vrhunskih povjesničara Istočne, Srednjoistočne i Jugoistočne Europe s težištem na istraživanju društva i politike u modernoj srednjoeuropskoj povijesti te s ciljem da se umreži veći broj istraživača s obiju strana hladnoratovske granice. Prije svega, bili su to: Tony Judt, Jan T. Gross, István Deák, Daniel Chirot i neki drugi s kojima je Roksandić surađivao kao najmlađi u toj skupini. Kao gostujući predavač surađivao je sa Srednjoeuropskim sveučilištem (CEU) u Budimpešti, gdje je od 1995. do 2002. godine na sveučilišnom Odsjeku za povijest i u Jugoistočnoeuropskom institutu održavao nastavu za poslijediplomske studente i doktorande. Na kolegiju o komparativnim metodama, predmetu i temi kojoj će se Roksandić vraćati tijekom svoje karijere na različite načine, a koja je integrirana u njegov temeljni pristup, surađuje s Jiř́jem Musilom i Alfredom J. Rieberom. Osim toga, gostovao je na još nekoliko bitnih europskih sveučilišta: na Université Paris 8 bio je gostujući profesor u ožujku - travnju 1998., a u rujnu 2001. godine gost-istraživač na hrvatsko-francuskom projektu na Sveučilištu u Strasbourgu. U ožujku 2004. godine kao directeur d'études invité étranger na l'École pratique des hautes études držao je predavanja na Sorbonni. U kolovozu 1998. godine bio je Senior Fellow u bonskom Zentrum für Europäische Integrationsforschung. Po pozivu je kao predavač i podnositelj priopćenja sudjelovao u radu oko 200 međunarodnih konferencija u Europi (Austrija, Belgija, Bosna i Hercegovina, Bugarska, Crna Gora, Češka, Francuska, Grčka, Italija, Izrael, Luksemburg, Mađarska, Njemačka, Poljska, Rusija, Slovenija, Srbija, Španjolska, Švicarska, Turska, Ukrajina, Velika Britanija i Hrvatska), Aziji (Japan) i Sjevernoj Americi (Kanada, Sjedinjene Američke Države). Pored toga, održao je više desetaka javnih predavanja u Hrvatskoj te Austriji, Bosni i Hercegovini, Mađarskoj, Njemačkoj, SAD-u, Srbiji, Rumunjskoj i Španjolskoj.

Godine 2000. - 2002. bio je pročelnik Odsjeka za povijest i predstojnik Zavoda za hrvatsku povijest Filozofskog fakulteta u Zagrebu. Član je uredništva triju međunarodnih časopisa: Austrian History Yearbook (od 2001. dopisni član), Balkanologie (Pariz, od 2001.), Ekonomska i ekohistorija (od 2005. član Uredništva i predsjednik Međunarodnog uredničkog vijeća te neko vrijeme i glavni urednik). Bio je voditelj, odnosno suvoditelj više istraživačkih projekata (npr. „Povijest političke misli u Hrvatskoj", „Nacionalno i 
jugoslavensko u srednjoškolskim udžbenicima povijesti“, „Le fait militaire dans les états et les sociétés du Sud-Est européen“, "Kulturni identitet i povijesno pamćenje“, „Triplex Confinium“) i voditelj jednog istraživačkog programa („Triplex Confinium“). Zahvaljujući međunarodnoj prepoznatljivosti projekta "Triplex Confinium", Drago Roksandić pozvan je da bude član velikoga međunarodnog projekta "Phantomgrenzen in Ostmitteleuropa“, koji je trajao od 2011. do početka 2017. godine. ${ }^{6}$

Od 1996. godine, kao voditelj međunarodnog projekta "Triplex Confinium: hrvatska višegraničja u euromediteranskom kontekstu“, posvetio je veći broj svojih radova istraživanjima "višegraničja“ (multiple borderlands) na hrvatskom te prostoru Jugoistočne Europe, na kojem su se u ranom novom vijeku sukobljavali i sustjecali imperijalni sustavi Habsburške Monarhije, Mletačke Republike i Osmanskog Carstva. Osim što problematiku „višegraničja“ sagledava iz kombiniranih mikrohistorijskih i makrohistorijskih perspektiva, otvarajući tako vjerojatno i novu razinu - neka vrsta mezzo-storia razine, o kojoj je i sâm češće govorio - Roksandićev pristup istraživanju tih problematika nužno je komparatistički i interdisciplinaran. Tako široko postavljena metodološka osnova njegovih radova omogućuje i danas produbljivanje ranije definiranih istraživačkih interesa. To je u konkretnom smislu značilo približavanje hrvatske historiografije onim pristupima koji su od 1980-ih godina osmanističkim studijama, potom onima vezanima uz povijest Mletačke Republike te naročito habsburškim studijama postavljali suvremene nadogradnje na ranije temelje. Pritom Roksandić nije samo pratio trendove habsburških studija koje su se razvijale osobito u Sjedinjenim Američkim Državama pod okriljem novih metoda i pristupa, već je uvelike anticipirao koncepcije i inovacijske razvojne smjerove koji do danas obilježavaju tzv. "New Habsburg History“. Bitno je obilježje njegova rada kultiviranje timske istraživačke djelatnosti pa je tijekom njegova djelovanja na Odsjeku za povijest i u sklopu Centra za komparativnohistorijske i interkulturne studije uspostavio svojevrsnu historiografsku školu. Osim toga, Roksandić je uvijek ulagao i poseban napor da se recentne znanstvene spoznaje što prije na primjeren način uvedu u nastavu. Projektom „Triplex Confinium“ omogućio je dolazak nekolicine znanstvenih novaka u Zavod za hrvatsku povijest Filozofskog fakulteta Sveučilišta u Zagrebu, danas nastavnika na Odsjeku za povijest (Z. Blažević, N. Štefanec, H. Petrić i M. Šarić). Time su projektne djelatnosti dobile posebnu kvalitetu u poticanju kako individualnog tako i kolektivnog rada suradnika te širenju suradnje u Hrvatskoj i svijetu.

Kao jedan od primjera inovacija u historiografiju koje je Drago Roksandić poticao spomenimo uvođenje ekohistorije u hrvatsku historiografiju, što je omogućilo da se brojni radovi iz hrvatske kulturne baštine ponovno počnu čitati na nov način, ali i da se konceptualno počne mijenjati odnos prema hrvatskoj povijesti s ekohistorijskog stajališta. ${ }^{7}$ Što to sve disciplinarno, teorijski i praktično znači, Drago Roksandić pokazao je i dvama prijevodnim projektima koji uključuju i njegove tekstove - Povijest europskog okoliša

6 Projekt je utemeljen u suradnji Instituta za povijesne znanosti pri Humboldt Sveučilištu, Centra Marc Bloch, Centra za Moderni Orijent u Berlinu te Povijesnog instituta pri Martin Luther Sveučilištu u Halle-Wittenbergu.

7 Treća međunarodna projektna konferencija, održana na Filozofskom fakultetu u Zadru 2000. godine, bila je posvećena ekohistoriji, a bila je ujedno i prva ekohistorijska konferencija ne samo u Hrvatskoj nego i u Jugoistočnoj Europi. V. Roksandić - Ivan Mimica - Nataša Štefanec - Vinka Glunčić-Bužančić (ur.), Triplex Confinium (1500-1800). Ekohistorija, Split - Zagreb 2003. 
Roberta Delorta i Françoisa Waltera (Zagreb 2002.) i Zapadna Hrvatska. Studija iz humane geografije Andréa Blanca (Zagreb 2003.). ${ }^{8}$

Za Roksandićevo shvaćanje problema „višegraničja“, kao i projektne istraživačke problematike ključno je djelo Triplex Confinium ili o granicama i regijama hrvatske povijesti 1500-1800 (2003.). Ta knjiga ustvari u intelektualnom smislu nastaje u duljem trajanju od samih početaka autorova stručnog rada, predstavljajući ne samo poveznicu između hrvatske historiografije i europskih istraživanja (F. Braudel, L. Febvre, D. Nordman i dr.) već i profiliran smjerokaz daljnjim pristupima ranonovovjekovnoj povijesti. ${ }^{9}$ Istraživački definirajući „višegraničje“ u mikrohistorijskoj i makrohistorijskoj perspektivi, Roksandić mijenja odnos i prema strogo razlučenom poimanju "centra" i "periferije“ u novijim socioekonomskim i sociokulturnim istraživanjima. lako su oba pojma epistemološki i dalje neizbježna, civilizacijski i kulturno kompleksna, policentrična i poliperiferična „višegraničja“ čine hrvatsku baštinu ranoga novog i novog vijeka „izazovom“ na europski izniman, a ipak višestruko prepoznatljiv način.

Godine 2001. u Zavodu za hrvatsku povijest sa svojim projektnim suradnicima (Z. Blažević - prva tajnica Centra, K. Milković, H. Petrić, M. Šarić i N. Štefanec) inicirao je stvaranje Centra za komparativnohistorijske studije, koji je dvije godine kasnije preimenovan u Centar za komparativnohistorijske i interkulturne studije. Od utemeljenja do umirovljenja bio je njegov voditelj. Osim toga, u sklopu Centra bio je i programski voditelj projekta Sveučilišta u Zagrebu "Jankovic Castle“, koji je financirala Europska unija (2011. - 2014.). ${ }^{10}$ Centar je 20. studenoga 2005. godine revitalizirao svoj Program društveno-humanističkih i kulturoloških istraživanja „Desničini susreti“, izvorno utemeljen 1989. godine u Zavodu za hrvatsku povijest, ${ }^{11}$ koji se u proteklom razdoblju afirmirao kao znanstveno i kulturno najrazvijenija, dugoročno projicirana istraživačka, dijaloška i izdavačka djelatnost Centra. Brojna izdanja Biblioteke Desničini susreti, koju uređuju prof. dr. sc. Drago Roksandić i prof. Ivana Cvijović Javorina, te druge serije Centra omogućuju da se pretežan dio istraživačkih spoznaja objelodani. U okviru "Desničinih susreta“ uspostavio je suradnju s književnim povjesničarima i teoretičarima, ali i s nizom drugih znanstvenika. Svake se godine pojavljuje i zbornik radova koji proizlazi iz dinamike skupa i koji već skoro jedno desetljeće uređuju Drago Roksandić i Ivana Cvijović Javorina (2011. godine im se kao urednica pridružila i

8 Knjiga Roberta Delorta i Françoisa Waltera izašla je u francuskom izvorniku pod naslovom Histoire de I'environnement européen godinu dana ranije od prijevoda (2001.). Blancova Zapadna Hrvatska izvorno je tiskana 1957. u Parizu. Kao humana geografija, nastala iz "susreta“ francuske geografske i historiografske tradicije, u osnovi istog onog „susreta“ iz kojeg se razvijala tradicija Annales, jedno svoje egzemplarno djelo realizirala je na hrvatskim temama, i to u biti shvaćenima kao problematika "višegraničja“ (iako se A. Blanc ne koristi eksplicitno ovim pojmom). „Zapadna Hrvatska“ jest prijelazni, „pražni“ (A. Blanc) prostor između hrvatskih panonskih i jadranskih areala, koji se svojom povijesnom posebnošću, i to ne samo u ranom novom vijeku, istraživački prepoznaje kao jedan od ključnih za razumijevanje distinktivnih hrvatskih modernizacijskih i nacionalnointegracijskih "nedovršenosti“. Što takvi pristupi u radu Drage Roksandića konkretno danas znače, uočljivo je u člancima: „Dalmatinska zagora u ranome novom vijeku: pitanja za raspravu“, u: Dalmatinska zagora - nepoznata zemlja. Katalog izložbe, ur. Joško Belamarić Marko Grčić, Zagreb 2007, 185-196 i „Posavska krajina/granica od 1718. do 1739. godine“, Ekonomska i ekohistorija, 3/3, 2007, 62-82.

9 Roksandić, Triplex Confinium ili o granicama i regijama hrvatske povijesti 1500-1800, Zagreb 2003, VIII.

10 V. http://kula-jankovica.unizg.hr.

11 O tome piše u: Roksandić, „'Desničini susreti'. Prijedlog programa znanstvenih rasprava“, Naše teme, $33 / 4,1989,725-730$. 
Magdalena Najbar-Agičić). „Desničini susreti“ ponovno su, kao i neki raniji Roksandićevi pothvati, postali platforma te svojevrsna historiografska i interdisciplinarna "radionica“ za mlađe generacije povjesničara.

Drago Roksandić je kao sveučilišni profesor savjesno i kvalitetno obavljao svoje nastavne obveze. Autori ovog teksta mogu to i osobno posvjedočiti kao njegovi studenti na različitim razinama, ali i kao suradnici u nastavi regionalne povijesti ranog novog vijeka i 19. stoljeća. On je na Odsjeku za povijest do akademske godine 2005./2006. držao predavanja iz kolegija "Svjetska povijest u ranom novom vijeku“ te seminare, kolokvije i izbornu nastavu. Potom je preuzeo kolegij „Povijest Srednje i Jugoistočne Europe u ranom novom vijeku“, a od početka je izvodio i „,bolonjsku“ nastavu. Nastava koju izvodi odlikuje se komparativnim i interkulturnim pristupom te osobito uklapanjem povijesti hrvatskog prostora u europsku i svjetsku povijest. Brojne generacije studenata pamte i danas problemski orijentiranu nastavu i seminarske diskusije, zatim inzistiranje profesora Roksandića na tjednim kratkim esejima, brojnim izvorima i tehničkim pomagalima koje je uvodio u nastavu sa željom da studente upozna ne samo s recentnim imenima historiografije već $i$ da im širom otvori globalne i aktualne horizonte. $\mathrm{Na}$ (,,starom“) poslijediplomskom studiju Odsjeka za povijest izvodio je nastavu u sklopu kolegija „Hrvatska u europskom i svjetskom kontekstu“. Akademske godine 1996./1997. održavao je na Pedagoškom fakultetu u Puli nastavu iz kolegija "Svjetska povijest od 16. st. do 1870. godine“. Roksandić od umirovljenja prof. dr. sc. Petra Korunića preuzima i kolegij „Europske regije i hrvatska povijest u 19. stoljeću" na preddiplomskoj razini, u suradnji s prof. dr. sc. Zeljkom Holjevcem te kasnije asistentom na tom kolegiju Filipom Šimetinom Šegvićem.

Uvodio je nove kolegije iz europske i svjetske povijesti, a na početku Bolonjske reforme zajedno sa svojim projektnim suradnicima inicirao je uvođenje novog obvezatnog kolegija na reformiranoj preddiplomskoj nastavi povijesti „Europske regije i hrvatska povijest ranoga novog vijeka“. Time se u nas prvi put uvodi sustavno studiranje temeljne problematike hrvatske povijesti u regionalnim euromediteranskim kontekstima. Na Odsjeku za povijest sudjelovao je u nastavi na poslijediplomskom studiju "Hrvatska povijest“, kao i u izvođenju odsječkog poslijediplomskog doktorskog studija "Hrvatska moderna i suvremena povijest u europskom i svjetskom kontekstu", na kojem se istaknuo inovativnim pristupom. Bio je dugogodišnji nositelj kolegija „Teorije i metode u modernoj suvremenoj historiografskoj znanosti“, a pokrenuo je i izborni kolegij "Jadranska/mediteranska radionica“.

$\mathrm{U}$ regionalnom orijentiranju i afirmiranju sveučilišne nastave hrvatske povijesti na novim pretpostavkama poslije 1989. godine i državnog osamostaljenja Republike Hrvatske bio je važan reprezentativan međunarodni znanstveni skup "Komparativni studij povijesti Srednje i Jugoistočne Europe“ ", koji je realiziran na inicijativu i s njegovim posebnim doprinosom kao inicijatora i predsjednika Pripremnog odbora u Zagrebu 1994. godine. Bio je to prvi skup takve naravi u Europi uopće. Pored više vrhunskih stručnjaka iz niza europskih zemalja i Sjedinjenih Američkih Država, u pripremi i radu skupa znatan su udio imali i zagrebački studenti povijesti, koji su s jednim izuzetkom danas svi afirmirani profesionalci (T. Jakovina, Z. Nikolić, M. Škrabalo, D. Špelić i Z. Velagić).

Za potrebe nastave na dodiplomskom i poslijediplomskom studiju na Odsjeku za povijest inicirao je 1995. godine izradu čitanki radi inovativnijeg i učinkovitijeg izvođenja nastave, odnosno radi kvalitetnijeg uvođenja studenata u nastavu.

Godine 1994. utemeljio je "Hrvatsko-francusku povijesnu radionicu“ u suradnji s prof. dr. sc. Gabrijelom Vidan s Odsjeka za romanistiku Filozofskog fakulteta Sveučilišta u 
Zagrebu, a 1995. „Hrvatsko-njemačku povijesnu radionicu“, koje sustavno obrađuju izvore za hrvatsku povijest na francuskom, odnosno njemačkom jeziku te se interkulturno bave temama iz hrvatsko-francuske i hrvatsko-njemačke baštine. Godine 1995. konstituirao je „Diplomsku radionicu“, u koju su uključeni studenti koji kod njega pišu diplomske radove.

Pod mentorstvom ili komentorstvom prof. dr. sc. Roksandića od 1992. do umirovljenja na Odsjeku za povijest Filozofskog fakulteta Sveučilišta u Zagrebu diplomiralo je više od stotinu studentica i studenata, što potvrđuje njihovu povećanu zainteresiranost za teme koje je nudio kao diplomske radove, ali i za njegove metode znanstvenog rada koje studente osposobljavaju za znanstveno-istraživački rad utemeljen na suvremenim metodama povijesne znanosti. Pod mentorstvom dr. sc. Roksandića izrađeno je i obranjeno niz uspjelih magistarskih radova te doktorskih disertacija. Bio je mentor pri izradi većeg broja radova izrađenih u nastavi na diplomskom i poslijediplomskom studiju na Srednjoeuropskom sveučilištu u Budimpešti. Od akademske godine 1995./1996. do 2001./2002. bio je prvi mentor ili drugi mentor za 40 diplomskih radova, kao i mentor za tri doktorske disertacije. Bio je član povjerenstava za "Ph. D. Comprehensive Examination“, a na doktorandskom studiju povijesti na CEU-u zajedno s profesorima Alfredom Rieberom i Jiř́ijem Musilom bio je jedan od trojice profesora koji su držali jedini obvezatan doktorandski kolegij, fokusiran na komparativne metode.

Zahvaljujući njegovu zalaganju kao predstojnika Zavoda za hrvatsku povijest, poslije 2000. godine obnovljena je već gotovo zamrla izdavačka djelatnost toga Zavoda, koji sada često nastupa kao suizdavač knjiga suradnikâ Zavoda. Posljednje takvo izdanje drugi je dio dnevnika zagrebačkog biskupa Maksimilijana Vrhovca, objavljen 2017. godine. ${ }^{12}$ Drago Roksandić bio je organizator i moderator brojnih međunarodnih radionica s povijesnim temama, koje su znatnim dijelom inicirane u okviru projekta "Triplex Confinium“ ili su posredno u vezi s njime. Javno je predstavljao, redovito na kritički osmišljen način, desetke stručnih izdanja od ranih 1980-ih godina do danas u zemlji i svijetu. Održao je brojna predavanja i sudjelovao u raspravama na predavanjima u zemlji i inozemstvu o fenomenima suvremenog svijeta koji su u vezi s njegovim povijesnim istraživanjima. Prevodio je s francuskog i engleskog te uredio prijevode kako tekstova za skripta u vlastitim kolegijima tako i knjiga za nakladničke kuće. Član je redakcije i redoviti suradnik časopisa Prosvjeta, mjesečnika SKD-a „Prosvjeta“ u Zagrebu, član redakcije časopisa Tragovi, redoviti suradnik Ljetopisa te član uredništva još nekih izdanja. Bio je član uređivačkog odbora edicije Krležijana Leksikografskog zavoda "Miroslav Krleža“. Redovito surađuje s muzejima, arhivima i drugim povijesnim ustanovama u Hrvatskoj i inozemstvu.

Drago Roksandić nositelj je dvaju francuskih odličja: časnik Reda akademske palme (Officier dans l'Ordre des Palmes Académiques), visokog državnog odlikovanja koje mu je dodijeljeno 2004. godine radi unapređenja francusko-hrvatskih odnosa na području znanstvene i sveučilišne suradnje, te časnik Nacionalnog reda (Officier dans I'Ordre National du Mérite) za zasluge koje su mu dodijeljene 2014. zbog dugogodišnjeg zalaganja i promicanja sveučilišne i znanstvene francusko-hrvatske suradnje.

Profesor Drago Roksandić jedan je od naših najaktivnijih istraživača relevantnih tema novovjekovne hrvatske i europske povijesti. Pri tome je osnovna karakteristika njegova

12 Maksimilijan Vrhovac, Dnevnik / Diarium, sv. 2 (1810-1815.) (latinski tekst preveli na hrvatski i bilješkama popratili Metoda Hrg i Josip Kolanović), Croatica Christiana - Fontes 29, Zagreb 2017. 
rada suradnja s drugim znanstvenicima u okviru hrvatskih i međunarodnih projekata te prezentiranje istraživačkih rezultata na međunarodnim znanstvenim i stručnim skupovima. Karakterističan je njegov ustrajan napor da se recentne znanstvenoistraživačke spoznaje dosljedno primjenjuju, od rada u praksi, odnosno vlastite historiografske produkcije i radova drugih autora kojima je bio mentor ili ih je usmjeravao pri njihovoj izradi, do njegova djelovanja u nastavi, a odlika je što je motivirane studente sustavno uvodio u prakse istraživačkog rada. Rezultate znanstvenih istraživanja, nekih ostvarenih i zajedničkim radom pod njegovim vodstvom, često je prezentirao na više mjesta i u publikacijama u nizu država, čineći tako hrvatsku historiografiju prisutnom na međunarodnom planu. Drago Roksandić pokazao se svojim radom kao svestrani povjesničar. Dobro poznavanje europske i svjetske historiografije reflektiralo se na njegova istraživanja u smislu kritičke recepcije i sustavne prilagodbe u vlastiti idejno-koncepcijski okvir. Klasici historiografije, poput A. J. P. Taylora, Fernanda Braudela, Pierrea Vilara ili Erica Hobsbawma, među brojnim drugima, djelovali su na njega svojim istraživački utemeljenim, analitičkim, konceptualno promišljenim i dobro napisanim djelima. Pritom treba naglasiti da je njegov rad vrlo rijetko ograničen na strogo disciplinsko ili subdisciplinsko proučavanje. Njegova istraživanja nisu samo model suvremene interdisciplinarnosti. Gotovo je nemoguće odrediti Dragu Roksandića kao povjesničara koji proučava i piše isključivo o socijalnoj, intelektualnoj, vojnoj, političkoj (ili novoj političkoj), kulturnoj historiji itd. Bilo da se radilo o koncepcijama „višegraničja“, ekohistoriji ili nekim drugim Roksandićevim istraživanjima, u njegovu fokusu ostaju - slijedeći tako u suštini Marca Blocha i Luciena Febvrea - čovjek u vremenskim i prostornim dimenzijama, uzimajući pritom u obzir široku paletu istraživačkih koncepata, od povijesti mentaliteta, intelektualne povijesti i povijesti ideja sve do povijesti okoliša. Njegovo, pak, istraživačko usmjerenje na ranonovovjekovnu te povijest 19. i 20. stoljeća odražava se u brojnim radovima i knjigama koje su transepohalne naravi, obilazeći klasične kronološke i periodizacijske barijere, pritom zadržavajući i jasno i temeljito izražene epohalne odrednice. Kada bi bilo nužno izdvojiti područja na kojima je Drago Roksandić ostavio snažan biljeg, odnosno kada bismo pokušali usustaviti njegove istraživačke interese, to bi svakako bila područja metodologije i teorije historije te historiografija, potom istraživanja vezana uz povijest Srba u Hrvatskoj od pojedinačnih istaknutih osoba do sinteza te u najširem smislu radovi vezani uz hrvatsku i regionalnu povijest od ranog novog vijeka do kasnog 20. stoljeća. Vjerska tolerancija, povijest uskoka, predstavnici elita između mentaliteta i intelektualnih obzora (od, primjerice, filologa Save Mrkalja do feldmaršala Svetozara Borojevića i književnika Vladana Desnice), promjene u političkoj kulturi 19. (i 20.) stoljeća, procesi nacionalne integracije ili revolucije 1848./1849. godine te odnos historije i memorije samo su neke od tema koje je Roksandić u svojim radovima obuhvatio. Istraživanja vezana uz obitelj Desnica, lik i djelo Vladana Desnice i širi povijesni kontekst pružaju pritom model interdisciplinarnih intelektualnohistorijskih istraživanja jednog pojedinca u vremenu i prostoru. U tom je okviru izašla i nova knjiga Iluzije slobode. Ogledi o Vladanu Desnici (Zagreb 2017.). O njegovu - u novije vrijeme izraženijem - usmjerenju prema suvremenoj povijesti svjedoče knjiga Kultura hrvatskog antifašizma. Prvi kongres kulturnih radnika Hrvatske (Topusko, 25. - 27. lipnja 1944.). Između "mjesta pamćenja“ i kritičke refleksije (2016.) u koautorstvu s Vlatkom Filipčić Maligec, suradnja na projektu „Local Approaches to the Second World War in Southeastern Europe" na Sveučilištu Humboldt u Berlinu, kao i neka njegova novija istraživanja antifašizma u Dalmaciji. 
Osim toga, izuzetno je bitan aspekt Roksandićeva stručnog rada i djelovanja njegova urednička i izdavačka djelatnost. U sklopu raznih specijalističkih i pažljivo osmišljenih biblioteka ili edicija objavljen je tako pod njegovim uredničkim ravnanjem niz historiografski prepoznatljivih i značajnih djela, od prijevoda nekih klasika historiografije do izdanja uglednih hrvatskih povjesničara ili mladih istraživača. Ovdje ćemo samo izdvojiti inovativno usmjerenu Biblioteku „Homines, tempora, loci“ te Biblioteku Desničini susreti. Jednako tako važno je spomenuti i njegovu brigu da se sustavno objavljuju kvaliteta kritička izdanja izvora.

Otkako je profesor Roksandić otišao u mirovinu objavljene su mu, pored nekih članaka, i dvije nove autorske knjige. Čovjek i prostor, čovjek u okolišu. Ekohistorijski ogledi (Zagreb - Samobor 2018.) knjiga je koja okuplja na jednome mjestu njegove ekohistorijske tekstove nastale u duljem rasponu, obuhvaćajući razdoblje od ranog novog vijeka do 20. stoljeća, krećući se u širokom luku od konceptualnih pitanja do konkretnih problema revitalizacije baštine na dugoročno održiv način, prevladavanjem dihotomije cultura vs. natura. Istraživanju suvremene povijesti usmjerena je druga knjiga, Historiografija u tranziciji (Zagreb 2018.). Drago Roksandić je svojim radom utjecao na brojne suradnike, studente i kolege, a svojim javnim istupima i na širu javnost. Njegov rad osjeća se u brojnim profesionalnim inicijativama, a osobito u poticanju i podršci mladim znanstvenicima, od studentske dobi nadalje, koje je sustavno upućivao da se oblikuju kao inovativni istraživači, profesionalno kritički otvoreni i prema vlastitoj kulturi i prema svijetu. Vjerujemo da će tek buduće generacije postati svjesne važnosti njegova znanstvenog, pedagoškog, stručnog i javnog djelovanja. Rezultati generacija koje je godinama poticao na rad i odgojio neka mu budu najbolja zahvala.

Hrvoje Petrić Filip Šimetin Šegvić 